EETP Vol. 15, 2020, №. 4(58)

ISSN 1896-2327 / e-ISSN 2353-7787

DOI: $10.35765 /$ eetp.2020.1558.08

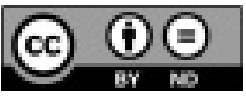

Nadesłano: 12.07 .2020

Zaakceptowano: 28.09 .2020

Sugerowane cytowanie: Jakubowicz-Bryx A. (2020). Zbilansowana dieta i zdrowa żywność w opiniach uczniów wczesnej edukacji, „Edukacja Elementarna w Teorii i Praktyce”, vol. 15, nr 4(58), s. 117-134. DOI: 10.35765/eetp.2020.1558.08

\author{
Anna Jakubowicz-Bryx \\ ORCID: 0000- 0001-6810-1631 \\ Uniwersytet Kazimierza Wielkiego w Bydgoszczy
}

\title{
Zbilansowana dieta i zdrowa żywność w opiniach uczniów wczesnej edukacji
}

\author{
Balanced Diet and Healthy Food in the Opinions \\ of Early Education Students
}

\section{SŁOWA KLUCZE ABSTRAKT}

zdrowa żywność, Tekst obejmuje problematykę zbilansowanej diety oraz zdrowej żywzbilansowana ności w perspektywie dziecka w młodszym wieku szkolnym. Słodycze, dieta, edukacja nadwaga, brak wiedzy na temat zbilansowanej diety i wiele innych wczesnoszkolna, czynników wpływa na nieprawidłowy rozwój. Zdrowa żywność stała promocja zdrowia, zagrożenia żywieniowe się pewnego rodzaju trendem. Coraz więcej osób stara się uprawiać sport, unikać niezdrowej żywności oraz przestrzegać zbilansowanej diety. Dorośli - rodzice, ale również szkoły i nauczyciele - starają się, by dzieci również posiadały wiedzę na temat zdrowego trybu życia i wiedziały, jak ważne jest to, co spożywamy. Młodsze dzieci szkolne coraz częściej uczone są o zagrożeniach wynikających ze spożywania niezdrowej żywności. W związku z powyższym celem przeprowadzonych badań było uzyskanie opinii uczniów we wczesnej edukacji na temat tego, czym jest zdrowa żywność i na ile badani uczniowie przestrzegają zbilansowanej diety podczas wyboru produktów żywnościowych. Poszukiwano odpowiedzi na pytania jaką wiedzę posiadają uczniowie klas III na temat zbilansowanej diety oraz jakie zagrożenia według nich wynikają ze spożywania niezdrowej żywności. Analiza wyników badań ujawniła, iż uczniowie posiadają odpowiednią wiedzę na temat zbilansowanej diety, którą czerpią najczęściej ze szkoły lub 
z Internetu, mimo to nie zawsze jej przestrzegają, a także fakt, że uczniowie często korzystają z posiadanej wiedzy na temat zbilansowanej diety, rozmawiają o zdrowej żywności z rodziną i znajomymi.

\section{KEYWORDS ABSTRACT}

healthy food, The text covers the issue of a balanced diet and healthy food from the balanced diet, early perspective of a child in early education. Sweets, overweight, the lack school education, of knowledge about a balanced diet, and many other factors affect health promotion, abnormal development of children. Healthy food has become a kind nutritional risks of a trend. More and more people are trying to play sports, avoid unhealthy food and follow a balanced diet. Adults, i. e. parents, but also teachers and other representatives of educational institutions, are trying to ensure that children know the principles of healthy lifestyle, which includes the knowledge of healthy eating. Nowadays, school children in early education are taught about the dangers of eating unhealthy foods more frequently than they were in the past. Therefore, the purpose of the research was to get their opinion about what healthy food is and to what extent they follow a balanced diet when choosing food products. The researchers were looking for the answers to questions concerning the knowledge of 3rd grade students about a balanced diet and about possible threats that may result from eating unhealthy food. The analysis of the research results has revealed that students have adequate knowledge about a balanced diet, which they usually get from school or from the Internet. However, the children do not always follow this diet. Also, the research has confirmed the fact that students often use their knowledge of a balanced diet and they talk about healthy food with their family and friends.

\section{Żywienie a rozwój dzieci w młodszym wieku szkolnym}

Według Platona zdrowie było, między innymi, funkcją doskonalenia stylu życia oraz kulturowej relatywizacji diety. Sposób życia w zdrowiu i radzenia sobie w chorobie są niezmiennie od tamtych czasów miernikami poziomu kultury. Coraz częściej poruszany jest temat zdrowego odżywiania się, a zdrowy tryb życia stał się pewnego rodzaju trendem. Dużo osób stara się dbać o dietę; jemy częściej, ale mniej.

Potrzeby żywieniowe dzieci i młodzieży w wieku szkolnym stanowią zagadnienie złożone, a zapotrzebowanie na energię i składniki pokarmowe nie jest jednoznacznie określone. Dzieci i młodzież w omawianym wieku rosnąc zmieniają się w rożny sposób. Zaczynają się osobnicze cechy rozwojowe i różne tempo wzrastania. To właśnie rzutuje 
na ich potrzeby żywieniowe i może czynić je różnymi w zależności od rozwojowego kształtowania się dziecka. Do 9-10 roku życia notuje się mniej więcej stale roczne przyrosty masy ciała w granicach 2,3-2,7kg. Po tym okresie życia obserwuje się powolny, ale stały wzrost przyrostu masy ciała. Jest to bowiem początek tzw. młodzieńczego skoku wzrostowego (Szotowa 2000: 27).

Dobry stan zdrowia z pewnością będzie oznaczał stały i wysoki poziom energii, równowagę emocjonalną, jasność umysłu, odporność na choroby zakaźne, umiejętność obrony przed nowotworami i chorobami układu krążenia, które to czynniki w rezultacie prowadzą do spowolnienia procesu starzenia i długiego życia.

Zważając na charakterystykę żywienia dzieci w młodszym wieku szkolnym, należy zauważyć, że

(...) inaczej niż na wcześniejszych etapach dzieciństwa, okres pomiędzy 5. rokiem życia a dojrzewaniem charakteryzuje się w zasadzie brakiem problemów żywieniowych i szybko zmniejszającym się zapotrzebowaniem na składniki odżywcze. Wzrastanie nadal stanowi czynnik wymagający zwiększonej ilości składników odżywczych w porównaniu z dorosłymi, ale uderzające jest to że pomimo zapotrzebowania związanego ze wzrastaniem i większą powierzchnią ciała dzieci w tym wieku nie mają dużo większego zapotrzebowania na energię i składniki odżywcze niż te poniżej 5. roku życia. Dzieci w tym wieku są coraz bardziej niezależne od rodziców i zaczynają mieć swoje poglądy na temat żywienia, aktywności fizycznej i zdrowia. Zaczynają odgrywać większą rolę w dostarczaniu pokarmów, które będą spożywać, ponieważ spędzają większą ilość czasu poza domem i chodzą do szkoły, co uniemożliwia im zakup posiłków i przekąsek. Edukacja na temat jedzenia, odżywiania się i zdrowia staje się więc priorytetem w prawidłowym rozwoju tych dzieci. Na tym etapie życia ważne jest, żeby dzieci odżywiały się zgodnie z zasadami zdrowego żywienia i piramidą żywieniową w celu rozwinięcia odpowiednich nawyków żywieniowych (mniejsze spożycie tłuszczów na rzecz produktów skrobiowych oraz owoców i warzyw) (Langley-Evans 2014: 131-132).

Istotne jest zatem, aby obserwować dziecko i uczyć od najmłodszych lat spożywania posiłków odpowiednich dla organizmu człowieka. Zauważyć można, że problem stosowania niewłaściwej diety zwiększa się z upływem lat. Dla przeciętnego, teraz już dorosłego człowieka „coś słodkiego” to nic innego jak np. owoc taki jak jabłko. Zdarza się, że dorośli wychodzą z założenia, że skoro sami w dzieciństwie otrzymywali zgodę swoich rodziców na spożywanie słodyczy, to ich dzieciom też powinno się na to pozwalać. Niestety wielu dorosłych nie czyta etykiet zamieszczonych na opakowaniach. Przeciętny człowiek nie wie, że dzisiejsze słodycze to w znacznym zakresie „chemia” i w związku z tym należy zapobiegać nadmiernemu spożywaniu tego typu produktów przez młode pokolenie, z zachowaniem pełnej równowagi spożycia określonych produktów. „Istotą zdrowego odżywiania jest kierowanie się zasadą, że należy spożywać różnorodne pokarmy, dostarczając organizmowi niezbędnych składników 
do prawidłowego funkcjonowania. Składniki, które potrzebuje każdy człowiek, aby zachować harmonijny rozwój to: węglowodany, białka, tłuszcze, witaminy, sole mineralne i mikroelementy" (Żuchelkowska 2013: s. 108).

Jak podaje P. Ilska „nawyki żywieniowe dzieci nie są łatwe do zmiany, gdyż szybko przyzwyczajają się do swoich ulubionych potraw i smaków. Jednak warto powalczyć o ich zdrowie weryfikując zasoby, jakimi w tej sprawie może dysponować szkoła oraz rodzice. Kluczem, jak zwykle, jest zaangażowanie wszystkich zainteresowanych i... pomyst, jak trafić do dzieci” (Ilska 2017: 27). Bardzo często możemy spotkać się z taką sytuacją, kiedy dziecko je potrawy tylko z wybranych składników. I właśnie tu pojawia się problem, jak to jedzenie przemycić, aby dziecku urozmaicić dietę, aby spróbowało czegoś nowego, aby małymi krokami zmieniać jego nawyki żywieniowe. Najistotniejsze w edukacji żywieniowej jest to, by wybierana żywność wzajemnie się uzupełniała i pokrywała dzienne zapotrzebowanie na określone produkty, a w nich składniki odżywcze. Na potrzeby żywieniowe wpływają: wiek, płeć, stan zdrowia i fizjologia organizmu oraz aktywność. Określone są również zasady żywienia dzieci (Laska 2004: 150). Wszystko za sprawą tego, że punktem wyjścia promocji zdrowia można uznać szeroko rozumiany dobrostan wielu sfer człowieka, któremu przyświeca namnażanie potencjału zdrowotnego. Natomiast w profilaktyce mamy do czynienia z działaniem mającym na celu utrzymanie obecnego stanu zdrowia oraz przeciwdziałanie czynnikom chorobotwórczym. Dlatego też pojęcia te mogą wzajemnie się przenikać, jednak działania w obu przypadkach możemy uznać za odrębne i idące w innych kierunkach (Kowalczewska-Grabowska 2013: 165-166).

Nadrzędnym celem i efektem uczenia się kilkulatków powinna być zmiana zachowań w kierunku prozdrowotnym, osiągnięta poprzez:

- zdobywanie nowej wiedzy i identyfikowanie własnych zaburzeń zdrowotnych,

- kształtowanie postaw i przekonań związanych ze zdrowiem i stanem choroby,

- rozwijanie odpowiedzialności nie tylko za swoje zdrowie ale też innych osób,

- zmianę systemu wartości oraz poznanie nowych wartości,

- kształtowanie postaw związanych ze zdrowiem fizycznym oraz zdolności psychospołecznych (Woynarowska 2017: 97).

Mówienie o zdrowym odżywianiu, o zdrowych posiłkach, nie likwiduje niestety istniejącego problemu, o którym mówi się również głośno. Jest to problem otyłości u dzieci, który bardzo mocno wiąże się z dobrym samopoczuciem i zdrowiem. Wbrew panującym współcześnie trendom promującym zdrowy tryb życia, w zastraszającym tempie wzrasta liczba dzieci, których dotyka problem otyłości. Mimo że popularne jest uprawianie sportu, a społeczeństwo stara się nakłonić swoich bliskich do wspólnych ćwiczeń oraz zmian w diecie, nadal spotyka się osoby, które nie widzą nic złego 
w spożywaniu produktów wysokokalorycznych. Eksperci uważają, że ustawa o bezpieczeństwie żywności i żywienia mogłaby zapoczątkować zmiany w przyzwyczajeniach spożywczych dzieci. Wszak „promocję zdrowia można określić jako sztukę pomagania człowiekowi, mającej na celu zmianę jego życia na lepsze" (Wolny 2010: 20).

„W porównaniu z Europą, 11-latkowie są grubsi niż ich rówieśnicy w innych krajach, najbardziej niepokojący jest fakt, że skala problemu wciąż narasta. W raporcie NIK rekomenduje, by w placówkach oświatowych zachęcać uczniów do spożywania warzyw, owoców i produktów mlecznych. Aby osiągnąć ten cel, proponuje się wspólne spożywanie śniadań uczniów z nauczycielami” (Kubala-Kulpińska 2018: 33). Ważne jest, aby w takiej sytuacji wspierać dziecko, być dla niego oparciem, ponieważ bez tego nie przezwycięży walki z tym problemem. Dziecko chętniej przyłączy się do ćwiczeń, jeżeli będzie miało osobę, która również z zaangażowaniem podejście do zaistniałej sytuacji. W ramach rozpoczęcia można umówić się z dzieckiem na zrobienie wspólnego planu działania, aby razem robić tygodniową listę zakupów, razem ustalać jadłospis. Zawsze więcej czasu dziecko spędzi z rodzicem, jeżeli będą wspólnie np. gotować. Ważne jest również podkreślenie tego, że można znaleźć sposoby przeciwdziałania z otyłością wśród uczniów. „Aktywność fizyczna jest najlepszym sposobem na zużytkowanie nadmiaru energii, rozładowanie napięcia, a także ma ogromny wpływ na prawidłowy rozwój dziecka. Warto podejmować działania mające na celu podwyższenie świadomości opiekunów uczniów, gdyż to oni kształtują nawyki żywieniowe dzieci oraz postawy prozdrowotne" (Kubala-Kulpińska 2018: 33-35).

Istotnym czynnikiem wpływającym na stan odżywiania dzieci są zachowania żywieniowe rodziny (Jarosz 2008: 99-100). Definiuje się je jako działanie dążące do zdobycia pożywienia. Postępowanie to jest niełatwe i zdeterminowane przez liczne czynniki genetyczne, w tym wytwarzanie hormonów, neurotransmiterów, kształtowanie narządów zmysłu, jak i działanie czynników środowiskowych czy kulturowych. Wiedza na temat urozmaicenia oraz wartości pożywienia, ilości składników odżywczych potrzebnych do aktualnego zapotrzebowania organizmu, ma również duże znaczenie, ponieważ wpływa na zachowania żywieniowe (Aue 2006: 201-204).

\section{Zdrowa żywność i jej znaczenie w opiniach uczniów klasy III - w świetle badań własnych}

W dzisiejszych czasach możemy być pełni świadomi sposobu bycia, sposobu, w jaki się odżywiamy, co w pełni koresponduje z promocją zdrowia, ze zdrowym odżywianiem. Coraz częściej słyszymy „jesteś tym, co jesz”, co wskazuje na to, że bardzo dużą uwagę zwracamy na jedzenie, na to, z jakich składników składają się posiłki, skąd pochodzą, co w sobie zawierają, oraz na to, jak spędzamy czas wolny, czy jest 
on bierny, czy raczej aktywny. Ma to wpływ na samopoczucie, energię, a wszystko to składa się na zdrowie. Pojawia się ważna kwestia poznania wiedzy i opinii uczniów na temat zdrowego odżywiania się w celu zminimalizowania spożywania przez uczniów „śmieciowego jedzenia” oraz możliwości wprowadzenia zmian żywieniowych uczniów w szkołach.

Celem przeprowadzonych badań było uzyskanie opinii uczniów we wczesnej edukacji na temat tego, czym jest zdrowa żywność i na ile badani uczniowie przestrzegają zbilansowanej diety podczas wyboru produktów żywnościowych. Problem główny skonstruowano w postaci pytania: Jaka jest wiedza uczniów klasy III na temat zdrowej żywności? Z powyższego pytania wynikają następujące problemy szczegółowe:

- Jaką wiedzę posiadają uczniowie klas III na temat zbilansowanej diety?

- Jakie zagrożenia wynikają ze spożywania niezdrowej żywności w opinii uczniów klas III?

W jaki sposób badani zdobywają wiedzę na temat zdrowej żywności?

- W jakim stopniu płeć różnicuje wiedzę uczniów klasy III o zdrowej żywności?

Metodą wybraną do badań był sondaż diagnostyczny z techniką ankiety. Wyniki zebrano z wykorzystaniem kwestionariusza ankiety skonstruowanego w taki sposób, aby poznać zdanie badanych na temat ich upodobań żywieniowych oraz dowiedzieć się, czym w opinii ankietowanych jest zdrowa żywność. Kwestionariusz wypełniło 114 uczniów klas III (63 dziewczynki i 51 chłopców) trzech szkół podstawowych w Bydgoszczy.

Prezentację wyników otwiera analiza kwestii wiedzy ankietowanych uczniów klas III na temat zdrowej żywności. Badani udzielali odpowiedzi na temat tego, skąd na ten temat czerpią wiedzę.

Tabela 1. Źródła wiedzy na temat zdrowej żywności

\begin{tabular}{|c|c|c|c|c|}
\hline \multirow{2}{*}{ Kategorie odpowiedzi } & \multicolumn{2}{|c|}{ Dziewczynki } & \multicolumn{2}{c|}{ Chłopcy } \\
\cline { 2 - 5 } & L & $\%$ & L & $\%$ \\
\hline z internetu & 8 & 12,70 & 21 & 41,18 \\
\hline ze szkoły (apele, lekcje wychowawcze, konkursy) & 27 & 42,86 & 14 & 27,45 \\
\hline od rówieśników & 4 & 6,35 & 2 & 3,92 \\
\hline od rodziców & 4 & 6,35 & 4 & 7,84 \\
\hline od rodziny (brat, siostra, babcia, dziadek, wujek, ciocia) & 6 & 9,52 & 1 & 1,96 \\
\hline z telewizji & 5 & 7,94 & 6 & 11,76 \\
\hline
\end{tabular}




\begin{tabular}{|c|c|c|c|c|}
\hline \multirow{2}{*}{ Kategorie odpowiedzi } & \multicolumn{2}{|c|}{ Dziewczynki } & \multicolumn{2}{|c|}{ Chłopcy } \\
\cline { 2 - 5 } & L & $\mathbf{\%}$ & $\mathbf{L}$ & $\mathbf{\%}$ \\
\hline z gazet & 5 & 7,94 & 2 & 3,92 \\
\hline z książek & 4 & 6,35 & 1 & 1,96 \\
\hline
\end{tabular}

Źródło: badania własne.

Jak warto zauważyć - ujawniają się dwa główne źródła wiedzy trzecioklasistów. U dziewcząt źródłem są apele, konkursy i lekcje w szkole, natomiast chłopcy czerpią swą wiedzę głównie z internetu. Niewielki udział w poznawaniu zasad żywienia według uczniów mają ich rodzice, rodzina czy rówieśnicy.

Zdrowe odżywianie to również zbilansowana liczba posiłków w ciągu dnia. Kolejne zestawienie prezentuje wyniki dotyczące liczby faktycznie spożywanych posiłków przez dzieci oraz ich opinię w kwestii tego, ile powinno się spożywać posiłków dziennie.

Tabela 2. Liczba spożywanych posiłków na dzień

\begin{tabular}{|c|c|c|c|c|c|c|c|c|}
\hline \multirow{2}{*}{$\begin{array}{c}\text { Kategorie } \\
\text { odpowiedzi }\end{array}$} & \multicolumn{4}{|c|}{$\begin{array}{c}\text { Liczba spożywanych posiłków } \\
\text { na dzień }\end{array}$} & \multicolumn{3}{c|}{$\begin{array}{c}\text { Liczba posiłków, jaką powinno się } \\
\text { spożywać na dzień }\end{array}$} \\
\cline { 2 - 9 } & Dziewczynki & \multicolumn{2}{|c|}{ Chłopcy } & \multicolumn{2}{c|}{ Dziewczynki } & \multicolumn{2}{c|}{ Chłopcy } \\
\cline { 2 - 9 } & L & $\%$ & L & $\%$ & L & $\%$ & L & $\%$ \\
\hline 2 posiłki & 5 & 7,94 & 8 & 15,69 & 11 & 17,46 & 14 & 27,45 \\
\hline 3 posiłki & 16 & 25,40 & 9 & 17,65 & 31 & 49,21 & 15 & 29,41 \\
\hline 4 posiłki & 34 & 53,97 & 28 & 54,90 & 15 & 23,81 & 14 & 27,45 \\
\hline $\begin{array}{l}5 \text { i więcej } \\
\text { posiłków }\end{array}$ & 8 & 12,70 & 6 & 11,76 & 6 & 9,52 & 8 & 15,69 \\
\hline
\end{tabular}

Źródło: badania własne.

Zestawienie wyników w Tabeli 2 uwidacznia znaczną różnicę pomiędzy wiedzą dzieci na temat ilości posiłków, jaką powinno się spożywać dziennie, a liczbą faktycznie spożywanych przez nich posiłków. Na plus dla rodziców można zaznaczyć, że większość dzieci zadeklarowała jedzenie 4 posiłków dziennie, jednak niepokojące są te odpowiedzi, które pokazują, że kilkunastu uczniów zjada tylko dwa posiłki dziennie. 
Podobnie zapytano uczniów o ilość płynów, jaką należy dziennie wypić, by utrzymać właściwe nawodnienie organizmu. Opinie uczniów prezentuje kolejne zestawienie wyników.

Tabela 3. Ilość wypijanych płynów dziennie

\begin{tabular}{|c|c|c|c|c|c|c|c|c|}
\hline \multirow{2}{*}{$\begin{array}{c}\text { Kategorie } \\
\text { odpowiedzi }\end{array}$} & \multicolumn{3}{|c|}{ Ilość wypijanych płynów dziennie } & \multicolumn{3}{c|}{$\begin{array}{c}\text { Ilość płynów, jaką powinno się } \\
\text { wypijać dziennie }\end{array}$} \\
\cline { 2 - 9 } & Dziewczynki & \multicolumn{2}{|c|}{ Chłopcy } & \multicolumn{2}{c|}{ Dziewczynki } & \multicolumn{2}{c|}{ Chłopcy } \\
\cline { 2 - 9 } & L & $\%$ & L & $\%$ & L & $\%$ & L & $\%$ \\
\hline $\begin{array}{c}0.751 \\
\text { dziennie }\end{array}$ & 19 & 30,16 & 8 & 15,69 & 14 & 22,22 & 11 & 21,57 \\
\hline 0,5 l dziennie & 34 & 53,97 & 27 & 52,94 & 32 & 50,79 & 28 & 54,90 \\
\hline 1 1 dziennie & 6 & 9,52 & 9 & 17,65 & 11 & 17,46 & 8 & 15,69 \\
\hline więcej niż 1 1 & 4 & 6,35 & 7 & 13,73 & 6 & 9,52 & 4 & 7,84 \\
\hline
\end{tabular}

Źródło: badania własne.

Specjaliści żywieniowi twierdzą, że dziecko w młodszym wieku szkolnym powinno wypijać około 1-1,5 1 płynów dziennie w zależności od aktywności ruchowej, jaką prezentuje. W tym kontekście wyniki zgromadzone w tabeli 3 mogą niepokoić. Nie tylko bowiem dzieci piją za mało płynów, ale także nie wiedzą, ile powinni dziennie wypijać. Ważne jest również to, co dzieci piją. Wyniki pokazuje Tabela 4.

Tabela 4. Rodzaje pitych płynów

\begin{tabular}{|c|c|c|c|c|}
\hline \multirow{2}{*}{ Kategorie odpowiedzi } & \multicolumn{2}{|c|}{ Dziewczynki } & \multicolumn{2}{c|}{ Chłopcy } \\
\cline { 2 - 5 } & L & $\%$ & L & $\%$ \\
\hline Woda & 34 & 53,97 & 27 & 52,94 \\
\hline Soki & 13 & 20,63 & 7 & 13,73 \\
\hline Herbata/kawa & 9 & 14,29 & 6 & 11,76 \\
\hline $\begin{array}{c}\text { Napoje gazowane (Coca- } \\
\text {-Cola, Sprite, Fanta) }\end{array}$ & 7 & 11,11 & 11 & 21,57 \\
\hline
\end{tabular}

Źródło: badania własne. 
Dla wieku rozwojowego najkorzystniejsze są oczywiście woda oraz soki, najlepiej świeżo wyciskane. $Z$ deklaracji badanych uczniów wynika, że ponad $70 \%$ dziewcząt i ponad $60 \%$ chłopców takie właśnie płyny pije. Niestety jest w tej grupie również 18 uczniów, którzy przyznają się do picia słodkich napojów gazowanych.

Wyjątkowo korzystnym składnikiem diety młodego człowieka są owoce. Zapytano więc o częstotliwość ich spożywania przez młodsze dzieci szkolne. Wypowiedzi uczniów zebrano w Tabelach 5 i 6.

Tabela 5. Częstotliwość spożywania owoców

\begin{tabular}{|c|c|c|c|c|}
\hline \multirow{2}{*}{ Kategorie odpowiedzi } & \multicolumn{2}{|c|}{ Dziewczynki } & \multicolumn{2}{c|}{ Chłopcy } \\
\cline { 2 - 5 } & L & \% & L & $\%$ \\
\hline Codziennie & 37 & 58,73 & 26 & 50,98 \\
\hline Kilka razy w tygodniu & 17 & 26,98 & 13 & 25,49 \\
\hline Raz na tydzień & 6 & 9,52 & 8 & 15,69 \\
\hline Nie jem owoców & 3 & 4,76 & 4 & 7,84 \\
\hline
\end{tabular}

Źródło: badania własne.

Dopełnieniem poprzedniego pytania jest informacja uzyskana od uczniów o rodzajach spożywanych owoców.

Tabela 6. Rodzaje spożywanych owoców

\begin{tabular}{|c|c|c|c|c|}
\hline \multirow{2}{*}{ Kategorie odpowiedzi } & \multicolumn{2}{|c|}{ Dziewczynki } & \multicolumn{2}{c|}{ Chłopcy } \\
\cline { 2 - 5 } & L & $\%$ & L & $\%$ \\
\hline Jabłka / gruszki & 26 & 41,27 & 13 & 25,49 \\
\hline Truskawki / maliny & 4 & 6,35 & 3 & 5,88 \\
\hline Banany & 14 & 22,22 & 23 & 45,10 \\
\hline Pomarańcze / mandarynki & 9 & 14,29 & 5 & 9,80 \\
\hline Brzoskwinie / nektarynki & 7 & 11,11 & 4 & 7,84 \\
\hline Winogrona & 3 & 4,76 & 3 & 5,88 \\
\hline
\end{tabular}

Źródło: badania własne. 
Deklaracje trzecioklasistów odnośnie do spożywania owoców mogą zadowalać. Okazuje się, że większość z nich je owoce codziennie lub co najmniej kilka razy w tygodniu. W diecie przeważają jabłka oraz banany - czyli z pewnością popularne owoce, które można zabrać ze sobą do szkoły na posiłek w przerwach między zajęciami.

Poza zdrową żywnością można zakładać, że również i ta niezdrowa pojawi się w diecie małych dzieci, choć nie powinna. Należą tu z pewnością słodycze oraz jedzenie typu fast food. Wyniki w tym zakresie prezentują kolejne zestawienia tabelaryczne. $\mathrm{Na}$ początek informacja od badanych uczniów o tym, jak często jedzą słodycze oraz jakie to są produkty.

Tabela 7. Częstotliwość spożywania słodyczy

\begin{tabular}{|c|c|c|c|c|}
\hline \multirow{2}{*}{ Kategorie odpowiedzi } & \multicolumn{2}{|c|}{ Dziewczynki } & \multicolumn{2}{c|}{ Chłopcy } \\
\cline { 2 - 5 } & L & $\%$ & L & $\%$ \\
\hline Codziennie & 9 & 14,29 & 10 & 19,61 \\
\hline Kilka razy w tygodniu & 11 & 17,46 & 9 & 17,65 \\
\hline Raz na tydzień & 4 & 6,35 & 3 & 5,88 \\
\hline Nie jem słodyczy & 39 & 61,90 & 29 & 56,86 \\
\hline
\end{tabular}

Źródło: badania własne.

Jak wynika z zestawienia danych w Tabeli 7, znaczący odsetek uczniów deklaruje, że nie je słodyczy w ogóle, bądź robi to rzadko. Kolejna tabela z pewnością zaprzecza tym stwierdzeniom.

Tabela 8. Rodzaje spożywanych słodyczy

\begin{tabular}{|c|c|c|c|c|}
\hline \multirow{2}{*}{ Kategorie odpowiedzi } & \multicolumn{2}{|c|}{ Dziewczynki } & \multicolumn{2}{c|}{ Chłopcy } \\
\cline { 2 - 5 } & L & $\%$ & L & $\%$ \\
\hline Batony/cukierki czekoladowe & 13 & 20,63 & 11 & 21,57 \\
\hline $\begin{array}{c}\text { Batony/cukierki bez } \\
\text { czekolady }\end{array}$ & 35 & 55,56 & 26 & 50,98 \\
\hline Lizaki/żelki & 9 & 14,29 & 6 & 11,76 \\
\hline Ciastka & 6 & 9,52 & 8 & 15,69 \\
\hline
\end{tabular}

Źródło: badania własne. 
Pytanie: „Jakie słodycze jesz?”, nie sąsiadowało w kwestionariuszu z pytaniem: „Czy jesz słodycze?”. Dało to niepokojący wynik. Dzieci z pewnością wiedzą, bądź są uczone, że nie powinny jeść słodyczy ze względu na ich szkodliwość. Natomiast pomimo posiadanej wiedzy wszystkie przyznały się do tego, że jakiegoś rodzaju słodycze jedzą - ponieważ wymieniły je w odpowiedzi na pytanie kwestionariusza.

Jeszcze bardziej niepokojące wyniki pokazuje zestawienie danych dotyczących odpowiedzi trzecioklasistów na temat spożywania tzw. fast foodów.

Tabela 9. Spożywanie produktów typu fast food

\begin{tabular}{|c|c|c|c|c|}
\hline \multirow{2}{*}{ Kategorie odpowiedzi } & \multicolumn{2}{|c|}{ Dziewczynki } & \multicolumn{2}{c|}{ Chłopcy } \\
\cline { 2 - 5 } & $\mathbf{L}$ & $\%$ & $\mathbf{L}$ & $\%$ \\
\hline Nie & 24 & 38,10 & 11 & 21,57 \\
\hline Tak & 39 & 61,90 & 40 & 78,43 \\
\cline { 2 - 5 } w tym: & 2 & 5,13 & 3 & \\
\hline Codziennie & 6 & 15,38 & 6 & 15,00 \\
\hline Kilka razy w tygodniu & 9 & 23,08 & 10 & 25,00 \\
\hline Raz na tydzień & 22 & 56,41 & 21 & 52,50 \\
\hline Raz na kilka tygodni & & & & \\
\hline
\end{tabular}

Źródło: badania własne.

Jedzenie typu fast-food w diecie małych dzieci nie powinno pojawiać się w ogóle. Jakże niepokojące są więc wyniki odpowiedzi dzieci na to, czy i jak często jedzą tego typu produkty. Prawie $62 \%$ dziewcząt oraz ponad $78 \%$ chłopców je takie dania. $\mathrm{Na}$ szczęście jednak, według ich deklaracji, nie robią tego częściej niż raz na kilka tygodni. Niestety pięcioro dzieci je takie posiłki codziennie, a dwanaścioro kilka razy w tygodniu. Stanowi to łącznie niecałe 15\% badanej populacji.

Wiadomo, że w szkołach nie sprzedaje się słodyczy ani napojów gazowanych. Automaty albo zostały usunięte ze szkół, albo ich zawartość wymieniona na inne produkty, które mogą być sprzedawane w szkołach. Warto więc poznać preferencje w zakresie kupowanych produktów w szkolnych sklepikach. Zestawienie wpisywanych przez uczniów produktów dostępnych w ich placówkach zawiera tabela 10. 
Tabela 10. Produkty kupowane przez dzieci w szkolnych sklepikach

\begin{tabular}{|c|c|c|c|c|}
\hline \multirow{2}{*}{ Kategorie odpowiedzi } & \multicolumn{2}{|c|}{ Dziewczynki } & \multicolumn{2}{c|}{ Chłopcy } \\
\cline { 2 - 5 } & L & $\%$ & L & $\%$ \\
\hline Płatki z mlekiem & 17 & 26,98 & 20 & 39,22 \\
\hline Soki/woda & 11 & 17,46 & 9 & 17,65 \\
\hline Galaretka & 21 & 33,33 & 16 & 31,37 \\
\hline Kanapki & 7 & 11,11 & 3 & 5,88 \\
\hline Owoce & 7 & 11,11 & 3 & 5,88 \\
\hline
\end{tabular}

Źródło: badania własne.

Jak wynika z zestawienia danych, najbardziej popularne w badanej populacji są płatki z mlekiem oraz galaretka. Niewielki odsetek kupuje owoce i kanapki. Kolejne pytanie dotyczyło więc tego, czy uczniowie zabierają do szkoły produkty, których nie mają możliwości zakupienia w sklepikach szkolnych, kioskach czy maszynkach z różnego rodzaju przekąskami. Odpowiedzi uczniów zebrano w Tabeli 11.

Tabela 11. Produkty żywieniowe zabierane przez dzieci do szkoły

\begin{tabular}{|c|c|c|c|c|}
\hline \multirow{2}{*}{ Kategorie odpowiedzi } & \multicolumn{2}{|c|}{ Dziewczynki } & \multicolumn{2}{c|}{ Chłopcy } \\
\cline { 2 - 5 } & $\mathbf{L}$ & $\%$ & L & $\%$ \\
\hline Nie & 9 & 14,29 & 3 & 5,88 \\
\hline \multirow{2}{*}{ Tak, w tym: } & 54 & 85,71 & 48 & 94,12 \\
\cline { 2 - 5 } & & & & \\
\hline Słodycze & 28 & 51,85 & 12 & 25,00 \\
\hline Napoje gazowane & 11 & 20,37 & 11 & 22,92 \\
\hline Chipsy & 4 & 7,41 & 6 & 12,50 \\
\hline $\begin{array}{c}\text { Drożdżówki i inne słodkie } \\
\text { bułki }\end{array}$ & 11 & 20,37 & 19 & 39,58 \\
\hline
\end{tabular}

Źródło: badania własne. 
Zdecydowana większość badanych uczniów przyznaje, że zabiera do szkoły produkty, których nie kupi w szkolnych sklepikach. I niestety okazuje się, że są to słodycze bądź ciastka i słodkie przekąski. Powstaje tu pytanie o rolę rodziców w kształtowaniu nawyków zdrowego żywienia dzieci, skoro pozwalają na tego typu zachowania.

Kolejne pytanie dotyczyło wyrażenia opinii uczniów na temat prowadzenia przez nich zdrowego trybu życia. Duży odsetek ankietowanych odpowiedział, że w ich opinii tryb życia, jaki prowadzą, jest jak najbardziej poprawny (Tabela 12).

Tabela 12. Prowadzenie zdrowego trybu życia

\begin{tabular}{|c|c|c|c|c|}
\hline \multirow{2}{*}{ Kategorie odpowiedzi } & \multicolumn{2}{|c|}{ Dziewczynki } & \multicolumn{2}{c|}{ Chłopcy } \\
\cline { 2 - 5 } & $\mathbf{L}$ & $\mathbf{0}$ & $\mathbf{L}$ & $\%$ \\
\hline Nie & 0 & 0,00 & 7 & 13,73 \\
\hline \multirow{2}{*}{ Tak, w tym: } & 63 & 100,00 & 44 & 86,27 \\
\cline { 2 - 5 } & & & & \\
\hline Uprawiam sport & 37 & 58,73 & 26 & 59,09 \\
\hline Nie jem słodyczy & 11 & 17,46 & 11 & 25,00 \\
\hline Jem dużo owoców i warzyw & 13 & 20,63 & 5 & 11,36 \\
\hline Piję dużo wody & 2 & 3,17 & 2 & 4,55 \\
\hline
\end{tabular}

Źródło: badania własne.

Wszystkie badane dziewczęta oraz ponad 86\% chłopców określa siebie jako osoby z pewnością prowadzące zdrowy tryb życia. Ponad połowa badanych uprawia sport. Znów pojawia się stwierdzenie o niejedzeniu słodyczy - chociaż wcześniej deklaracje były inne. Tym razem również bardzo słaby wynik uzyskało picie odpowiedniej ilości napojów, w tym wody.

Badani uczniowie mieli również za zadanie przedstawić swoje stanowisko na temat oddziaływania zdrowej żywności na samopoczucie oraz zdrowie fizyczne. Wyniki prezentują kolejne dwie tabele. 
Tabela 13. Zdrowa żywność a jej oddziaływanie na samopoczucie człowieka

\begin{tabular}{|c|c|c|c|c|}
\hline \multirow{2}{*}{ Kategorie odpowiedzi } & \multicolumn{2}{|c|}{ Dziewczynki } & \multicolumn{2}{c|}{ Chłopcy } \\
\cline { 2 - 5 } & $\mathbf{L}$ & $\mathbf{\%}$ & $\mathbf{L}$ & $\%$ \\
\hline Nie & 6 & 9,52 & 12 & 23,53 \\
\hline \multirow{2}{*}{ Tak, w tym: } & 57 & 90,48 & 39 & 76,47 \\
\cline { 2 - 5 } & & & & \\
\hline Dobry nastrój & 18 & 31,58 & 4 & 10,26 \\
\hline Więcej energii & 18 & 31,58 & 18 & 46,15 \\
\hline Mniej nerwów & 11 & 19,30 & 9 & 23,08 \\
\hline Ochota na zabawę & 10 & 17,54 & 8 & 20,51 \\
\hline
\end{tabular}

Źródło: badania własne.

Zdecydowana większość uczniów stwierdziła, że ich zdaniem zbilansowana dieta oddziałuje na dobre samopoczucie człowieka. Dziewczęta stwierdziły, że daje dobry nastrój i zwiększa energię, a chłopcy, że głównie daje więcej energii. W jeszcze większym zakresie to oddziaływanie zauważają uczniowie w kontekście zdrowia fizycznego.

Tabela 14. Zdrowa żywność a jej oddziaływanie na zdrowie fizyczne człowieka

\begin{tabular}{|c|c|c|c|c|}
\hline \multirow{2}{*}{ Kategorie odpowiedzi } & \multicolumn{2}{|c|}{ Dziewczynki } & \multicolumn{2}{c|}{ Chłopcy } \\
\cline { 2 - 5 } & $\mathbf{L}$ & $\%$ & $\mathbf{L}$ & $\%$ \\
\hline Nie & 0 & 0,00 & 5 & 9,80 \\
\hline Tak, w tym: & 63 & 100,00 & 46 & 90,20 \\
\cline { 2 - 5 } & 28 & 44,44 & 12 & 26,09 \\
\hline $\begin{array}{c}\text { Mniejsze ryzyko zachorowań } \\
\text { (cukrzyca, otyłóć, choroby } \\
\text { serca) }\end{array}$ & 14 & 22,22 & 10 & 21,74 \\
\hline Zdrowe zęby & 6 & 9,52 & 12 & 26,09 \\
\hline Brak zmęczenia w ciągu dnia & 15 & 23,81 & 12 & 26,09 \\
\hline Lepsza sprawność ruchowa & & & & \\
\hline
\end{tabular}

Źródło: badania własne. 
Wszystkie dziewczęta oraz 90\% chłopców zauważa oddziaływanie zdrowej żywności na poprawę zdrowia człowieka. Dla dziewczynek głównie jest ważna ze względu na mniejsze ryzyko zachorowań, u chłopców odpowiedzi rozkładają się na wszystkie kategorie jednolicie.

\section{Podsumowanie i wnioski z badań empirycznych}

Zdrowa żywność jest bardzo ważnym elementem w życiu każdego człowieka, tak samo dorosłego, jak i najmłodszego. To, w jaki sposób dziecko jest uczone dobierania produktów spożywczych do swojej diety, jest bardzo istotną kwestią, która wywiera wpływ na jego dalsze życie. Dzieci w młodszym wieku szkolnym mają już wypracowane pewne nawyki żywieniowe. Zadaniem rodziców i nauczycieli jest wpajanie dzieciom odpowiednich nawyków oraz wartości żywieniowych. Wiek szkolny jest okresem, w którym dziecko potrafi podejmować samodzielne decyzje. Ważne więc jest uświadamianie dziecku, jaką rolę w jego życiu odgrywa każdy posiłek. Termin „śmieciowego” jedzenia jest już znany praktycznie każdemu. W szkołach temat zdrowej żywności jest bardzo popularny, a kadra nauczycielska stara się wpoić najmłodszym odpowiednie wartości dotyczące spożywania produktów.

Przygotowane i przeprowadzone badania miały na celu ukazanie wiedzy uczniów związanej ze zdrową żywnością oraz zagrożeniami braku zbilansowanej diety, której powinni przestrzegać. Jak wiemy, od niedawna w szkołach nie sprzedaje się słodyczy ani napojów gazowanych. Automaty albo zostały usunięte ze szkół, albo ich zawartość wymieniona na inne produkty, które mogą być sprzedawane w szkołach.

$\mathrm{Z}$ analizy otrzymanych odpowiedzi wynika, że uczniowie w badanej populacji starają się spożywać produkty zdrowe, a unikają bądź spożywają bardzo rzadko produkty wysokokaloryczne, czy produkty typu fast food. Twierdzić można, że w dużej mierze jest to zasługa nauczycieli, posiadających odpowiednią wiedzę na ten temat, jak i rodziców czy nawet mediów, które w pewnym stopniu starają się przekazać najmłodszym widzom, dlaczego ich produkt warto kupować. Mimo zakazu spożywania niezdrowej żywności w szkołach badani często pozwalają sobie na przynoszenie produktów, których nie mają możliwości zakupić w placówce szkolnej. Należy podkreślić, że odpowiedzialność za takie sytuacje ponoszą rodzice i opiekunowie najmłodszych, ponieważ to oni dają dzieciom pieniądze. Wszak to dziecko - albo samo, albo za namową kolegów i koleżanek, przeznacza pieniądze na coś zupełnie innego, niż powiedzieli rodzice. $Z$ przeprowadzonych badań wynika też, że uczniowie nie potrafią przyznać się do podjadania słodyczy. Zauważyć również można, że to dziewczęta bardziej zwracają uwagę na to, co jedzą i w jakich ilościach, za to chłopcy uprawiają częściej sport. Uczniowie są świadomi tego, jak ważne jest prawidłowe odżywianie się. Dzięki zajęciom 
przeprowadzanym przez nauczycieli w szkołach dzieci mają możliwość zapoznania się z zagrożeniami wynikającymi ze spożywania niezdrowej żywności. Często szkoła zachęca uczniów do zainteresowania się tematem zdrowej żywności poprzez organizowanie tematycznych konkursów oraz apeli. Zdarza się jednak, że dzieci, mimo że znają zagrożenia wynikające ze spożywania niezdrowej żywności, pozwalają sobie na spożywanie produktów, które wpływają na organizm dziecka negatywnie. Pocieszający jest fakt, że poza zajęciami w szkole ankietowani sami poszukują informacji na temat tego, co jeść i w jakich ilościach.

Sposobów na pozyskiwanie wiedzy na temat tego, co powinno się jeść i w jakich ilościach, żeby nasz organizm czuł się zdrowo, jest bardzo wiele. Reasumując odpowiedzi ankietowanych, zauważyć można, że uczniowie samodzielnie poszukują informacji dotyczących zbilansowanej diety poza szkołą, między innymi w sieci. Dzieci w młodszym wieku szkolnym są świadome, jakie zagrożenia płyną z nieprawidłowego odżywiania się, jak również widzą i znają korzyści płynące z prawidłowej diety. Warto zaznaczyć, że badani myślą pozytywnie zarówno o sobie, swoim ciele, jak i o efektach prawidłowego odżywiania się. Ważne jest również, że dzieci są pozytywnie nastawione do produktów, które są im proponowane zamiast słodyczy czy napojów gazowanych, w których przeważa cukier. Dzieci chętnie odwiedzają sklepik szkolny, w którym zamiast batonów czy lubianych przez nie chipsów, kupują płatki z mlekiem. Badania pokazały również, że w opinii uczniów zdrowa żywność ma znaczącą rolę w ich życiu oraz oddziałuje na samopoczucie ankietowanych trzecioklasistów.

Analiza wyników pozwoliła na sformułowanie w stosunku do badanej populacji następujących ustaleń:

1. Uczniowie posiadają odpowiednią wiedzę na temat zbilansowanej diety, którą czerpią najczęściej ze szkoły lub z internetu. Mimo to nie zawsze jej przestrzegają.

2. Uczniowie często korzystają z posiadanej wiedzy na temat zbilansowanej diety. Rozmawiają o zdrowej żywności z rodziną i znajomymi.

3. Uczniowie uważają, że częstym zagrożeniem dla organizmu związanym ze spożywaniem niezdrowej żywności jest między innymi otyłość, choroby serca czy problemy związane z uzębieniem. Mają świadomość zagrożeń, ale często poddają się pokusom.

4. Uczniowie zdobywają wiedzę na temat niezdrowej żywności często ze szkoły, od dorosłych, ale sięgają również do źródeł internetowych.

5. Badani uczniowie posiadają dużą wiedzę na temat zdrowego odżywiania się. Zdecydowana większość ankietowanych uczniów uprawia różnego rodzaju sporty oraz zamienia napoje słodkie na wodę mineralną.

6. Płeć badanych nie decyduje w znaczącym zakresie o wiedzy ankietowanych uczniów na temat zdrowego żywienia. 
Podsumowując, można stwierdzić, że wybór produktów promujących zdrowie ma wpływ na samopoczucie i sprawność fizyczną dzieci. W zakresie żywności powinno się spożywać produkty pochodzące z upraw ekologicznych, takich, które nie są poddawane intensywnemu chemicznemu nawożeniu i oddziaływaniu chemicznych środków, które mają za zadanie chronić dane rośliny. Pomimo zakazu spożywania produktów okrzykniętych mianem niezdrowych, uczniowie sami decydują o tym, co jedzą i w jakich ilościach. Wiedza uczniów w badanej populacji na temat zagrożeń płynących ze spożywania produktów niezdrowych jest dobra. Wielu badanych uczniów ma świadomość tego, co powinno się jessć i w jakich ilościach. Wiedzą, że żywność ma duży wpływ na dalszy rozwój człowieka. Można domniemywać, że coraz więcej rodziców rozmawia z dziećmi, tłumacząc im, dlaczego nie powinni jeść słodyczy i pić napojów gazowanych, ponieważ uczniowie dużą wiedzę i nawyki żywieniowe „przynoszą" z domu do placówki szkolnej. Często samodzielnie starają się zdobywać interesujące ich informacje związane ze zdrowym trybem życia. Dzieci chętnie dzielą się swoją wiedzą oraz biorą udział w zajęciach dotyczących promocji zdrowia i konkursach ogłaszanych przez szkołę. Po analizie wyników kwestionariusza ankiety można powiedzieć, że badani uczniowie mimo młodego wieku pozytywnie reagują na zdrowe nowości, które proponuje rynek.

\section{Bibliografia}

Aue W. (2006). Cztowiek w środowisku, Warszawa: WSiP.

Ilska P. (2017). Królowie warzyw i owoców, „Remedium” nr 5 (288), s.26-28.

Jarosz M. (2008). Zasady prawidtowego żywienia dzieci i mtodzieży oraz wskazówki dotyczace zdrowego stylu życia, Warszawa: Instytut Żywności i Żywienia.

Kowalczewska-Grabowska K. (2013). Promocja zdrowia w środowisku lokalnym, Katowice: Wydawnictwo Uniwersytetu Śląskiego.

Kubala-Kulpińska A. (2018). Nadwaga i otytość poważnym problemem dzieci i mtodzieży, „Życie Szkoły” nr 36, kwiecień, s. 33-35.

Langley-Evans S. (2014). Żywienie: wptyw na zdrowie cztowieka, Warszawa: Wydawnictwo Lekarskie PZWL.

Laska M. (2004). Edukacja żywieniowa, [w:] A. Jaczewski, K. Komosińska (red.), Wybrane zagadnienia z edukacji zdrowotnej (skrypt dla studentów), Płock: Wydawnictwo Naukowe NOVUM.

Szotowa M. (2000). Żywienie cztowieka zdrowego i chorego, Warszawa: Państwowe Wydawnictwo Naukowe PWN.

Woynarowska B. (red.). (2017). Edukacja zdrowotna. Podstawy teoretyczne. Metodyka. Praktyka, Warszawa: Polskie Wydawnictwo Naukowe.

Wolny B. (2010). Edukacja zdrowotna w szkole, Stalowa Wola: Wydawnictwo Diecezjalne i Drukarnia w Sandomierzu. 
Żuchelkowska K. (2013). Edukacja zdrowotna w przedszkolu, Bydgoszcz: Wydawnictwo Uniwersytetu Kazimierza Wielkiego.

\section{ADRES DO KORESPONDENCJI}

Anna Jakubowicz-Bryx

Uniwersytet Kazimierza Wielkiego w Bydgoszczy e-mail: annabryx@ukw.edu.pl 